\title{
PROSES KREATIF TIM DESAINER RANCANG BANGUN KENDARAAN TEMPUR KELAS RINGAN PT PINDAD
}

\author{
Hardy Adiluhung \\ Program Studi Desain Produk S1 Fakultas Industri Kreatif \\ Universitas Telkom \\ Jl. Telekomunikasi, No. 1, Terusan Buahbatu-Bojongsoang, Kec. Dayeuhkolot, Kota Bandung, Kode Pos 40257 \\ Jawa Barat. Indonesia \\ Email: hardydil@telkomuniversity.ac.id
}

\begin{abstract}
Abstrak
Suatu proses di balik perwujudan rancang bangun kendaraa tempur kelas ringan, tentunya ada ide berfikir Desainer, dan menjadi makna yang menarik ketika dideskprisikan melalui pembacaan ide dan ide yang mengiringi karya purwarupa. Metode penelitian yang digunakan metodologi penelitian deskriptif deduktif, penelitian deskriptif dimaksudkan untuk memberikan gambaran bahwa kreativitas pendukung dapat dimanfaatkan untuk menerapkan konsep berpikir kreatif dalam upaya menghasilkan gagasan dalam desain produk, dan memberikan gagasan bahwa sistem yang sama dapat dimanfaatkan juga sebagai tempat penyimpanan pengetahuan dari ide-ide tersebut. Penelitian deduktif, penelitian yang dimulai dari beberapa teori yaitu teori tentang pengembangan produk, inovasi dan teori berpikir kreatif, kemudian mengembangkan konsep ketiganya dan menerapkan konsep untuk ditarik kesimpulan. Hasil penelitian menunjukkan bahwa setiap desainer kendaraan tempur tentu saja dalam mendesain kebutuhan akan proses dalam bentuk ide, konsep, ide, gambar kerja dan selajutnya hasil akhir dalam bentuk desain purwarupa.
\end{abstract}

Kata Kunci: kendaran, desainer, berpikir kreatif, purwarupa.

\begin{abstract}
A process behind the realization of the design of a lightweight combat vehicle, of course there is a designer thinking idea, and it becomes an interesting meaning when described through the reading of the ideas and ideas that accompany the prototype work. The research method used is deductive descriptive research methodology, descriptive research is intended to provide an idea that supporting creativity can be used to apply the concept of creative thinking in an effort to generate ideas in product design, and provide the idea that the same system can also be used as a storage place for knowledge from ideas. the idea. Deductive research, research that starts from several theories, namely the theory of product development, innovation and creative thinking theory, then develops the three concepts and applies the concepts to draw conclusions. The results showed that every combat vehicle designer certainly needs a process in the form of ideas, concepts, ideas, work drawings and the final result is in the form of prototype designs.
\end{abstract}

Keywords: vehicle, designer, creative thinking, prototype.

\section{PENDAHULUAN}

Desain adalah proses yang bisa dikatakan seusia dengan keberadaan manusia di bumi. Ini sering tidak kita sadari. Akibatnya, sebagian dari kita berpendapat seolah-olah desain baru sudah dikenal sejak zaman modern dan merupakan bagian dari kehidupan modern. Dalam bahasa sehari-hari kata desain sering didefinisikan sebagai desain, rencana atau ide. Dalam hal ini jelas bahwa desain tidak hanya desain di atas kertas, tetapi juga seluruh proses sampai pekerjaan direalisasikan dan memiliki nilai. Desainnya tidak berhenti di atas ketas, tetapi merupakan kegiatan praktis yang mencakup juga elemen ekonomi, sosial, teknologi, dan budaya dalam berbagai dinamika. Salah satu contoh bidang desain adalah desain produk industri, adalah bidang yang memperdalam desain produk industri yang diproduksi secara massal.

Dalam proses desain, desain produk industri mempertimbangkan berbagai faktor yang berkaitan dengan produksi dan pengguna. Misalnya, seorang perancang produk industri dalam mendesain kendaraan, aspek yang perlu dipertimbangkan adalah bagaimana kendaraan ini nyaman bagi pengguna dan aman untuk dikendarai. Selain itu, yang terpenting adalah aspek estetika bentuk dan konfigurasi kendaraan ini, eksterior dan interior. Proses desain juga memperhitungkan sejauh mana teknologi yang dimiliki 


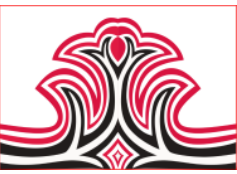

oleh pabrikan, sehingga nantinya desain yang dihasilkan layak untuk diproduksi.

Industri yang erat kaitannya dengan desain salah satunya adalah industri kendaraan militer, kebutuhan akan kendaraan militer pada periode ini cukup meningkat, di mana beberapa kegiatan militer masih sangat membutuhkan kendaraan tempur sebagai pendukung operasional. Salah satu contoh industri manufaktur di bidang kendaraan militer adalah PT. Pindad, yang memproduksi peralatan pertahanan, keamanan, dan peralatan industri lainnya di bawah wewenang Kementerian BUMN (Badan Usaha Milik Negara). Merancang kendaraan atau kendaraan tempur tentu saja dalam konteks desain perlu proses dalam bentuk ide, konsep, gambar kerja dan hasil akhir dalam bentuk sementara atau purwarupa sebagai bentuk awal sebelum menuju ke tingkat yang lebih tinggi, Produksi massal. Berdasarkan uraian di atas maka peneliti mencoba menganalisis Perancang proses kreatif, dalam mewujudkan gagasan purwarupa kendaraan tempur kelas ringan PT. Pindad. Penelitian ini dipilih dan digunakan sebagai objek untuk menganalisis proses kreatif di balik perwujudan purwarupa kendaran tempur kelas ringan PT. Pindad.

\section{KAJIAN TEORI}

Berpikir kreatif adalah urutan tindakan yang dilakukan orang dengan menggunakan pikiran mereka untuk menciptakan ide-ide baru dari kumpulan ingatan yang mengandung ide, deskripsi, konsep, pengalaman, dan pengetahuan. Pemahaman ini menunjukkan bahwa berpikir kreatif dicirikan oleh penciptaan sesuatu yang baru dari hasil berbagai ide, penjelasan, konsep, dan pengetahuan dalam pikiran. Sedangkan Evan menjelaskan bahwa berpikir kreatif adalah kegiatan menciptakan hubungan yang berkesinambungan, sehingga ditemukan kombinasi yang tepat atau hingga seseorang menyerah. Berpikir kreatif juga dapat dilihat sebagai proses yang digunakan ketika seseorang menghasilkan atau memunculkan ide baru. Ide baru ini merupakan kombinasi dari ide-ide sebelumnya yang belum pernah direalisasikan atau masih dalam pemikiran. Karena itu, dalam pemikiran kreatif, dua bagian otak akan sangat diperlukan. Keseimbangan antara logika dan intuisi sangat penting.

Berdasarkan dari beberapa pendapat di atas, dapat disimpulkan bahwa berpikir kreatif adalah aktivitas mental untuk menciptakan sesuatu yang baru, baik dalam bentuk ide maupun karya nyata dengan menggabungkan unsur-unsur yang telah ada sebelumnya. Diskusi pemikiran kreatif tidak akan lepas dengan istilah kreativitas yang merupakan hasil
Gorga : Jurnal Seni Rupa

Volume 10 Nomor 01 Januari-Juni 2021

p-ISSN: 2301-5942 | e-ISSN: 2580-2380

pemikiran kreatif. Kreativitas sering didefinisikan sebagai produk, atau hasil dari pikiran orang, orisinal dan berbeda dari yang sudah ada dengan kata lain kreativitas adalah produk dari pemikiran kreatif (creative thinking).

\section{Proses Berpikir Kreatif}

Mengetahui proses berpikir manusia kreatif, pedoman yang digunakan adalah proses kreatif yang dikembangkan oleh Wallas (dalam Munandar, 2002: 59) karena merupakan salah satu teori yang paling umum digunakan untuk mengetahui proses berpikir kreatif para penemu dan pekerja seni yang menyatakan bahwa proses kreatif meliputi empat tahap: a). Persiapan pada tahap pertama seseorang bersiap untuk menyelesaikan masalah dengan mengumpulkan data yang relevan, dan mencari pendekatan untuk menyelesaikannya, b). Inkubasi, pada tahap kedua, seseorang tampaknya melepaskan diri sementara dari masalah. Tahap ini penting sebagai awal dari proses inspirasi yang merupakan titik awal dari penemuan baru atau penciptaan dari wilayah pra-sadar, c). Penerangan pada tahap ketiga, seseorang mendapat pemecahan masalah diikuti dengan munculnya inspirasi dan ide-ide yang dimulai dan mengikuti munculnya inspirasi dan ide-ide baru, dan d). Penerapan model wallas untuk mengidentifikasi proses berpikir kreatif seseorang.

Pada tahap terakhir adalah tahap seseorang menguji dan memeriksa penyelesaian masalah dengan kenyataan. Di sini dibutuhkan pemikiran kritis dan konvergen. Pada tahap verifikasi seseorang setelah melakukan pemikiran kreatif harus diikuti oleh pemikiran kritis.

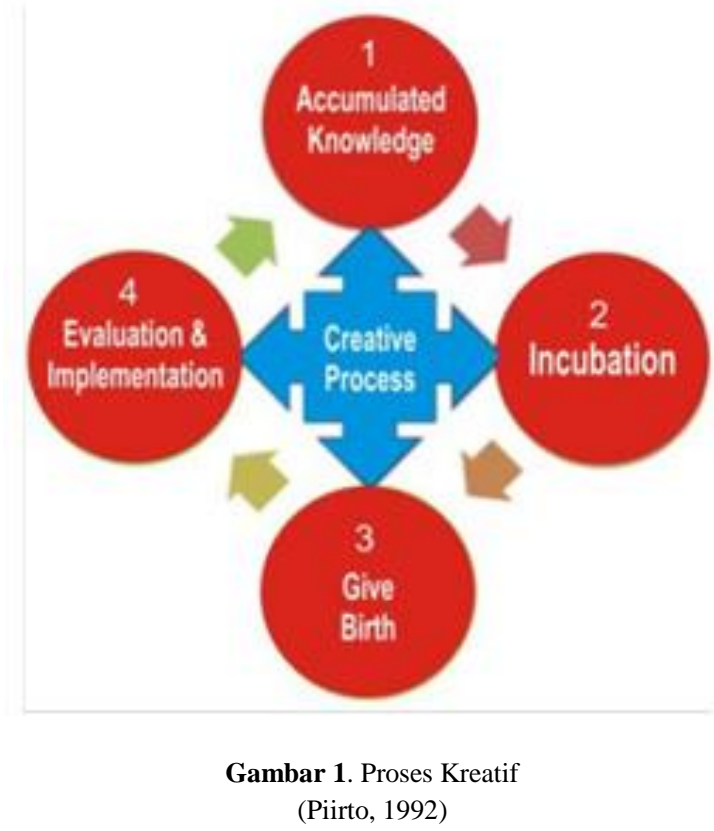




\section{Karakteristik Berpikir Kreaif}

Kreativitas umumnya merupakan ide yang mencakup area luas gaya gaya kognitif, kategori kinerja, dan berbagai manfaat (hasil). Kreativitas mengacu pada pemikiran yang berbeda dan produk yang diterima sebagai kreatif. Haylock (1997) menjelaskan dua pendekatan utama untuk mengenali pemikiran kreatif: a). Perhatikan respons subjek terhadap penyelesaian masalah, di mana proses kognitif tertentu, yaitu memahami karakteristik pemikiran kreatif yang diharapkan berhasil. Bagaimana mengatasi perbaikan (mengatasi fiksasi), berpikir keluar dari kebiasaan (memecah set mental), b). Tentukan kriteria suatu produk yang merupakan indikator pemikiran kreatif. Cara melihat produksi yang berbeda yang mencakup fleksibilitas, keaslian, dan kesesuaian (appropriatness). Menurut Guilford (dalam Supriadi, 1997: 7) Karakteristik kemampuan berpikir kreatif ada lima, yaitu: 1). Kefasihan berfikir, yaitu memicu banyak ide, jawaban, pemecahan masalah dan pertanyaan, menyediakan banyak cara atau saran untuk melakukan sesuatu dan selalu memikirkan lebih dari satu jawaban, 2). Keterampilan fleksibilitas, yang menghasilkan beragam ide, jawaban atau pertanyaan, dapat melihat masalah dari berbagai perspektif, mencari berbagai alternatif atau arah, dan dapat mengubah cara pendekatan atau cara berpikir, 3). Keterampilan berpikir orisinal, yang mampu melahirkan ekspresi baru dan unik, memikirkan cara mengekspresikan diri yang tidak konvensional dan mampu membuat kombinasi bagian atau elemen yang tidak biasa, 4). Keterampilan terperinci atau elaborasi, yang mampu memperkaya dan mengembangkan ide atau produk, dan menambah atau merinci detail suatu objek, ide atau situasi sehingga lebih menarik, dan 5). Keahlian redefinisi, yang menentukan apakah pertanyaan itu benar, rencana yang sehat, atau tindakan yang bijaksana, mampu mengambil keputusan tentang situasi terbuka, dan tidak hanya memicu gagasan tetapi juga melakukannya.

Seorang desainer produk mengembangkan dan mengeksplorasi berbagai alternatif melalui gambar dan model, kemudian mempersempit desain yang diarahkan dengan melakukan pemilihan alternatif melalui tolok ukur kebutuhan pengguna dan kemampuan manufaktur. Untuk mengatasi kerumitan proses produksi massal, perancang produk perlu menguji pengujian produk untuk memastikan bahwa suatu produk memenuhi kebutuhan, keinginan dan harapan penggunanya, dan sering mengatur ulang komponen atau bagiannya untuk membuat produk lebih efisien untuk diproduksi dan mudah untuk merakit, memperbaiki dan mendaur ulang. Seorang desainer produk harus memiliki. Kreativitas itu muncul tidak hanya dengan banyaknya alat dan bahan yang bisa diolah, namun bagaimana caranya membuat bahan yang terbuang menjadikannya karya baru hasil dari kreativitas seseorang (Azis, 2018).

\section{METODE PENELITIAN}

Dibalik manifestasi sebuah prototipe, ternyata ada pergulatan pikiran sang Desainer, dan menjadi makna yang menarik ketika diekspresikan dengan membaca ide-ide dan ide-ide yang menyertai karya prototipe tersebut. Sigmund Freud melihat kreativitas sebagai hasil dari mengatasi masalah. Orang kreatif dipandang sebagai seseorang yang telah memiliki pengalaman traumatis, dihadapkan dengan membiarkan ide-ide tidak sadar dan tidak sadar untuk berbaur menjadi solusi inovatif, sehingga dalam proses kreatif seorang desainer dapat membentuk proses kreatif dan bagaimana gambar abstrak dan gambar konkret dapat menjadi kenyataan, untuk memvisualisasikan bentuk prototipe berdasarkan perencanaan desain.

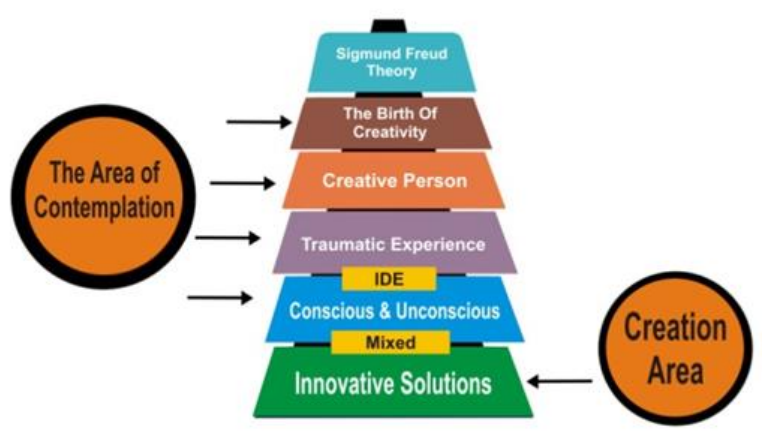

Gambar 2. Proses Pemecahan Inovatif (Sigmund, 1917)

Sigmund Freud menggambarkan proses kreatif mekanisme pertahanan, yang merupakan upaya tidak sadar untuk menghindari kesadaran akan ide-ide yang tidak menyenangkan atau tidak dapat diterima. Jadi biasanya mekanisme pertahanan menghambat produktivitas kreatif. Meskipun sebagian besar mekanisme pertahanan menghambat tindakan kreatif, mekanisme sublimasi justru merupakan penyebab utama kreativitas. Terkait dengan proses kreatif ini akan menjadi manifestasi dari seorang desainer, maka proses berpikir kreatif sebenarnya lebih personal, dapat ditemukan stimulus dan ide-ide kreatif yang dikreasikan dalam bentuk refleksi diri baik dalam bentuk ide-ide dan makna awal yang dapat dipahami secara pribadi oleh Desainer di bidang abstrak.

Proses kreatif adalah pemikiran dari ide-ide yang terus dikembangkan dan ada perubahan dalam setiap pemikiran. Intervensi pihak lain selama proses kreatif 
dapat terjadi, jika Desainer meminta pertimbangan mereka yang dianggap memiliki kompetensi di bidangnya. Namun, pada dasarnya proses kreatif adalah wahana bagi kreativitas Desainer untuk mewujudkan keaslian desain yang menjadi tujuannya. Dalam hubungan ini, perancang umumnya berusaha dengan konsentrasi, pengaruh yang dapat mengganggu ekspresi ekspresinya.

Dalam teori psikoanalisis, struktur kepribadian manusia terdiri dari id, ego dan superego. Id adalah komponen kepribadian yang mengandung impuls agresif dan libinal, di mana sistem bekerja dengan prinsip kesenangan kesenangan. Ego adalah bagian kepribadian yang berfungsi sebagai eksekutif, di mana sistem bekerja pada dunia luar untuk menilai realitas dan berhubungan dengan dunia batin untuk mengelola id impuls agar tidak melanggar nilai-nilai superego. Superego adalah bagian moral dari kepribadian manusia, karena itu adalah filter dari sensor akal sehat, secara keliru, mungkin sesuatu yang didorong oleh ego untuk dilakukan.

Kekuatan untuk membangun bentuk ide-ide kreatif, pada kenyataannya, berakar pada ego diri, yang diputuskan melalui refleksi diri. Berkaitan dengan itu, interpretasi selalu menjadi simbol, sebagai penemuan pikiran, yang mendukung pernyataan sikap atas masalah yang mengganggu para desainer itu sendiri. Perwujudan ide dalam desain prototipe tank kelas menengah terbangun di atas pikiran sadar, sadar, dan tidak sadar. Ini bisa dirasakan selama proses kreatif, seperti bagaimana kendaraan tank tempur dapat bertahan di medan perang dan melawan musuh dengan kemampuan yang tangguh. Tetapi dalam kontrol antara pikiran sadar dan ambang sadar, sistem kerja, menciptakan ide dalam memecahkan masalah secara kreatif. Demikian pula, untuk berpikir lebih jauh, setiap tahap mendesain ide atau ide datang melalui pemikiran pikiran bawah sadar atau kemampuan berpikir yang tingkat di luar logika, tetapi ini akan menjadi nilai tambah dalam menemukan ide dari Ide-ide liar, mungkin saja keluar bisa menjadi ide pengganti, yang akan membantu mengungkap yang tersembunyi, dan memunculkannya dalam kesadaran melalui interaksi antara elemen-elemen ini.

\section{HASIL DAN PEMBAHASAN}

\section{Hasil}

Dalam menghasilkan ide, tentu perlu untuk membatasi dari setiap elemen dan mempertimbangkan, dan melihat apakah ide-ide itu mengandung sesuatu yang sesuai untuk diharapkan, tentu saja tidak perlu menyulitkan diri dengan mengikuti sejauh mana ide-ide itu membawa kita pada pemikiran yang kita capai.

Kreativitas desainer sebagai kotak hitam, metode kotak hitam adalah metode berpikir intuitif dan juga disebut imagining, karakteristik utamanya adalah: target desain tidak ditentukan dan dapat berubah sesuai dengan perkembangan pemikiran perancang serta input data tambahan. Keputusan desainer dikendalikan oleh input data terbaru tentang masalah yang dihadapi, serta input dari kasus yang hampir identik atau analog, ditambah input dari pengalaman sendiri desainer. Desainer keputusan dapat diambil lebih cepat tetapi acak sambil mengabaikan prevalensi masyarakat atau sebaliknya untuk mengakomodasi dan mengikuti kehendak mereka. Dalam benak perancang untuk mencerna dan memanipulasi gambar yang mewakili struktur masalah secara menyeluruh, maka dengan cara yang sering tidak dapat diprediksi untuk mengubah masalah kompleks menjadi sederhana dan pada saat yang sama menghasilkan keputusan akhir. Dalam metodologi desain, proses ini sering disebut lompatan wawasan.

\section{Pembahasan}

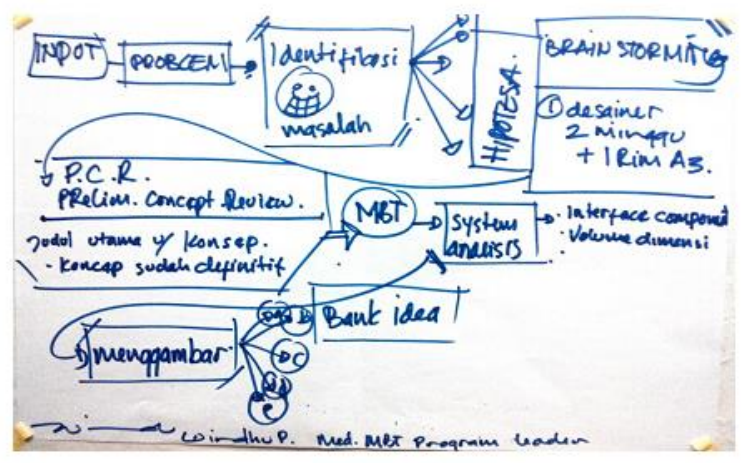

Gambar 3. W Paramanta, "Paparan Pengembangan Ide" (Adiluhung, 2017)

Visualisasi pengembangan ide adalah bentuk fisik dari suatu desain yang telah diatur dalam benak seseorang, yang bertujuan agar suatu gagasan dapat divisualisasikan sehingga gagasan tersebut dapat disampaikan dengan benar dan sesuai dengan tujuan penyampaian pesan, berpikir keluar dari aturan umum yang ada, tanpa kriteria / ide 'gila', sebagai ide pencapaian. Bentuk pencapaian ide bisa berupa simbol atau sketsa. Sketsa adalah desain awal dalam upaya untuk mentransfer informasi verbal menjadi informasi visual.

Sketsa gambar pada prinsipnya adalah catatan visual dalam menyampaikan ide, diwujudkan dengan pemilihan dan pemisahan data visual yang diproses melalui indera mata, proses keterampilan melalui keterampilan tangan dalam proses pengolahan melalui 
media, dan ketepatan dalam mempertimbangkan keseimbangan rasa dan rasio keseluruhan. Pada gilirannya, keterampilan dan kepekaan ini akan berkontribusi pada peringkat nilai dan kualitas.

Di sisi praktis serta kesederhanaan teknis dalam proses pembuatan, sktsa berada pada tahap awal dalam hierarki penciptaan karya monumen lainnya. Pada level ini gambar sketsa dapat diartikan sebagai desain awal dan gambar kerja dalam mewujudkan desain, baik dalam bentuk 2 dimensi maupun 3 dimensi. Sketsa sebagai unit terkecil dalam proses kerja, yang juga berfungsi sebagai karya desain, secara teknis biasanya ditandai dengan pembuat informasi penting, dalam bentuk bentuk studi, warna, teknik kerja dalam bentuk gambar detail, close up atau gambar khusus dalam sisipan, kecil atau skema. Fungsinya untuk dengan mudah diterjemahkan kembali selama eksekusi pada desain desain. Membuat sketsa dengan objek yang sama juga sering dilakukan dengan alterant jika ada komposisi, bentuk, proporsi, dan ukuran (skala) yang berbeda untuk menghasilkan karya terbaik.

Dengan demikian pada tahap proses sketsa, seorang desainer memiliki kesempatan untuk mengembangkan kreativitas ide seluas mungkin. Metode yang digunakan sebagai sketsa sebagai laboratorium, dalam menemukan bentuk kemasan ide ini menjadi penting untuk mengurangi risiko kegagalan dalam mewujudkan desain desain. Setelah berhasil membuat sketsa, langkah selanjutnya yang perlu diambil adalah membuat desain yang komprehensif. Dalam desain komprehensif ini tampilan visual dari informasi yang akan dikomunikasikan mendekati final.

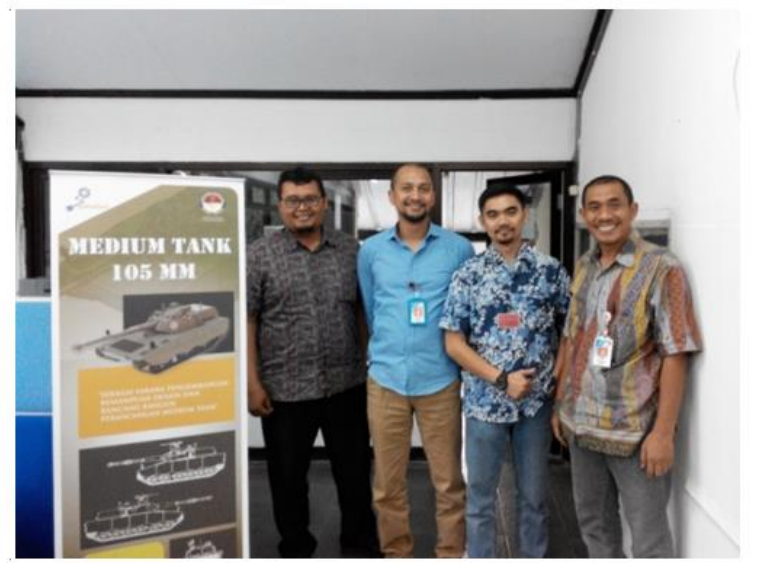

Gambar 4. Photo Bersama Tim Proyek (Adiluhung, 2017)

\section{KESIMPULAN DAN SARAN}

\section{Kesimpulan}

Proses kreatif adalah pemikiran dari ide-ide yang terus dikembangkan dan ada perubahan dalam setiap
Gorga : Jurnal Seni Rupa

Volume 10 Nomor 01 Januari-Juni 2021

p-ISSN: 2301-5942 | e-ISSN: 2580-2380

pemikiran. Intervensi pihak lain selama proses kreatif dapat terjadi, jika Desainer meminta pertimbangan pihak-pihak yang dianggap memiliki kompetensi di bidangnya. Proses kreatif adalah wahana bagi kreativitas Desainer untuk mewujudkan keaslian desain yang menjadi tujuannya. Dalam hubungan ini, perancang umumnya berusaha dengan konsentrasi, pengaruh yang dapat mengganggu ekspresi ekspresinya.

Dalam desain kendaraan tempur, proses awalnya merupakan bentuk kekacauan yang masih perlu diklarifikasi. Dalam desain lahir ide, perancang tim dari divisi kendaraan khusus Pindad diperlukan untuk merancang kendaraan tempur, ini tentu merupakan hal baru dalam desain. studi ini terbatas pada pendukung aliran pemikiran kreatif sebagai tahap generasi ide dari proses desain.

\section{Saran}

Usaha untuk menciptakan persaingan yang semakin kompetitif dalam persaingan produk, perusahaan tertentu tidak memiliki sumber daya yang cukup untuk mengembangkan produk. Beberapa komponen dan bagian pendukung yang ada digunakan sebagai bagian dari komponen pendukung. Seorang desainer haruslah memiliki bank ide untuk dapat mengimplementasikan saat sekarang maupun akan datang, dalam menghadapi persaingan dunia, sehingga industri mampu bertahan dan memiliki kemampuan produk yang dapat bersaing.

\section{DAFTAR RUJUKAN}

Adiluhung, Hardy. (2017). "Proses Kreatif". Hasil

Dokumentasi Pribadi: 05 Mei 2017, Universitas Telkom.

Azis, A. C. K. (2018). Sampah Anorganik Menjadi Kerajinan Tas pada Kelompok Program Keluarga Harapan (PKH) di Kecamatan Deli Tua. Jurnal Pengabdian Kepada Masyarakat, 24(2), 689-694.

Haylock, D. (1997). Recognising Mathematical Creativity In School Children. http://www.fiz.karlsruhe.de/fiz/publications/z dmZDM (diakses tanggal 27 Maret 2021).

Munandar, Utami. (2002). Pengembangan Kreativitas Anak Berbakat. Jakarta: Rineka Cipta.

Piirto, J. (1992). Those Who Create. Ohio: Ohio Psychology Press.

Sigmun, Freud. (2006). Pengantar Psikoanalisis Umum. Yogyakarta: Pustaka Pelajar.

Supriadi, D. (1997). Kreativitas, Kebudayaan \& Perkembangan IPTEK. Bandung: Alfabeta. 